\title{
Production and quality of carrot in function of split application of nitrogen doses in top dressing
}

\author{
Lidiane F Colombari'; Natália BL Lanna ${ }^{1}$; Leysimar RP Guimarães; Antonio Ismael Inácio Cardoso ${ }^{1}$ \\ ${ }^{1}$ Universidade Estadual Paulista (UNESP-FCA), Botucatu-SP, Brasil; colombarifl@yahoo.com.br; nataliabritovrb@yahoo.com.br; \\ leysimarpitzr@yahoo.com.br; ismaeldh@fca.unesp.br
}

\begin{abstract}
Fertilizers supply in the appropriate period and dose is important to obtain satisfactory production. In this research we studied the effect of different split applications and doses of nitrogen in top dressing on the production of the carrot and the physicochemical characteristics of the roots. Nine treatments, resulting from a factorial of $4 \times 2+1$ (control without nitrogen fertilization), were evaluated in the randomized blocks experimental design, with four replications. The first factor were four nitrogen $(\mathrm{N})$ doses in top dressing (60, 90,120 and $\left.150 \mathrm{~kg} \mathrm{ha}^{-1}\right)$ and the second were two forms of splitting [three equal applications $(1 / 3+1 / 3+1 / 3$ of the dose) and one with increasing proportions $(1 / 6+2 / 6+3 / 6$ of the dose $)$ applied 15,30 and 50 days after emergence]. We evaluated shoot height, fresh and dry shoot weight, fresh and dry root weight, root diameter and length, yield and some physicochemical characteristics of roots (soluble solids, titratable acidity, maturation index, $\mathrm{pH}$, carotenoid content and reducing sugars). For most of the studied characteristics were observed quadratic effects for $\mathrm{N}$ dose, with an estimated maximum yield of $117.7 \mathrm{t} \mathrm{ha}^{-1}$ for the dose of $138 \mathrm{~kg} \mathrm{~N} \mathrm{ha}^{-1}$. The splitting $1 / 6+2 / 6+3 / 6$ resulted in higher values for fresh weight of shoot and root, root diameter, yield and carotenoid content, compared to the splitting $1 / 3+1 / 3+1 / 3$.
\end{abstract}

Keywords: Daucus carota, carotenoids, fertilization, root quality, yield.

\section{RESUMO}

Produção e qualidade da cenoura em função do parcelamento de doses de nitrogênio em cobertura

O fornecimento dos adubos na época e nas doses adequadas é importante para a obtenção de uma produtividade satisfatória. Desse modo, objetivou-se estudar formas de parcelamento e doses de nitrogênio em cobertura na produção de cenoura e nas características físico-químicas das raízes. Foram nove tratamentos, resultantes de um fatorial $4 \times 2+1$ (testemunha sem adubação nitrogenada em cobertura), avaliados no delineamento experimental em blocos ao acaso, com quatro repetições. $\mathrm{O}$ primeiro fator consistiu de quatro doses de nitrogênio em cobertura (60; 90; 120 e $\left.150 \mathrm{~kg} \mathrm{ha}^{-1}\right)$ e o segundo de duas formas de parcelamento [três aplicações iguais $(1 / 3+1 / 3+1 / 3$ da dose) e um com proporção crescente ( $1 / 6+2 / 6+3 / 6$ da dose), aplicados aos 15, 30 e 50 dias após a emergência]. Foram avaliados a altura da parte aérea, massa da matéria fresca e seca da parte aérea e da raiz, diâmetro, comprimento e produtividade das raízes e algumas características físico-químicas das raízes (sólidos solúveis, acidez titulável, índice de maturação, $\mathrm{pH}$, teor de carotenóides e açúcares redutores). Para a maioria das características estudadas obtiveram-se efeitos quadráticos para as doses de nitrogênio em cobertura, com máxima produtividade $\left(117,7 \mathrm{tha}^{-1}\right)$ estimada para a dose de $138 \mathrm{~kg}$ de $\mathrm{N} \mathrm{ha}^{-1}$. No parcelamento $1 / 6+2 / 6+3 / 6$ foram obtidos maiores valores para massa da matéria fresca da parte aérea e da raiz, diâmetro da raiz, produtividade e teor de carotenóides.

Palavras-chave: Daucus carota, adubação, carotenóides, produtividade, qualidade das raízes.

Received on May 4, 2017; accepted on May 2, 2018

$\mathrm{N}$ itrogen is a nutrient often lacking in plant nutrition, being an element of high mobility, easily getting lost by volatilization or leaching (Alves et al., 2009). Nitrogen losses are also intensified in sandy soils, due to lack or absence of aggregator elements such as organic matter and clay. Due to the losses, less than $50 \%$ of the supplied nitrogen is tapped by plants during their development (Bredemeier \& Mundstock, 2000).
In cultures generally, a small part of the nitrogen is provided before sowing along with phosphorous and potassium, and the remainder distributed in top dressing, one or more times, coinciding with the time of higher demand of culture (Silva et al., 2004). The greater the number of applications in covering the most is used by carrot plant (Vieira Filho et al., 2014).

For carrots, of the applied nitrogen, about 10 to $15 \%$ is absorbed at the beginning and at the end of their growth and the remaining $85-90 \%$ during the growth phase of the plant (Moniruzzaman et al., 2013). These authors showed that during its various stages of growth, the plant needs different amounts of nutrients, this is, when the plant is young, the absorption of nutrients is small, then it follows a period of logarithmic accumulation and during the final period there occur a stabilization phase. 
Due to different requirement of nutrient amounts during the growth stages and, due to rapid loss of nitrogen, the fertilizer supply at the phase of greater demand in the recommended doses is important. So, plants respond to this practice with higher production using lower quantity of fertilizers, being possible the reduction of costs. Thus, it established the hypothesis that the supply of this nutrient in top dressing through different application times could provide better utilization by the plants in their stages of higher nutritional requirement. Thus, the aim of this research was to study the effect of different forms and nitrogen application doses in top dressing on the production and physicochemical characteristics of carrot roots.

\section{MATERIAL AND METHODS}

The study was conducted at the São Manuel Experimental Farm, located in São Manuel-SP (22 $44^{\prime} 28^{\prime} \mathrm{S}$, 48 34'37''W; $740 \mathrm{~m}$ altitude), belonging to the UNESP in Botucatu-SP.

The soil is a Typical Red Dystrophic Latosol, sandy soil. The chemical analysis (0-20 cm depth) resulted: $\mathrm{pH}=$ $5.3, \mathrm{M} . \mathrm{O}=7 \mathrm{~g} \mathrm{dm}^{-3}, \mathrm{P}_{\text {resin }}=40 \mathrm{mg} \mathrm{dm}^{-3}$, $\mathrm{H}+\mathrm{Al}=20 \mathrm{mmol}_{\mathrm{c}} \mathrm{dm}^{-3}, \mathrm{~K}=1.9 \mathrm{mmol}_{\mathrm{c}}$ $\mathrm{dm}^{-3}, \mathrm{Ca}=37 \mathrm{mmol}_{\mathrm{c}} \mathrm{dm}^{-3}, \mathrm{Mg}=6 \mathrm{mmol}_{\mathrm{c}}$ $\mathrm{dm}^{-3}, \mathrm{SB}=45 \mathrm{mmol}_{\mathrm{c}} \mathrm{dm}^{-3}, \mathrm{CTC}=65$ $\mathrm{mmol}_{\mathrm{c}} \mathrm{dm}^{-3}$ and $\mathrm{V}=70 \%$.

Two months preceding the implantation of the experiment, soil was limed to elevate the base saturation to $80 \%$, which is the recommended saturation for planting carrot. On planting date, soil was fertilized at a 20$\mathrm{cm}$ depth with a rotary tiller bed former with $360 \mathrm{~kg} \mathrm{ha}^{-1}$ of formulated 4-14-8, complementing the amounts of nitrogen and potassium with ammonium sulfate and potassium chloride, respectively.

Nine treatments, a factorial scheme $4 \times 2+1$ (control without nitrogen fertilization), were studied. The first factor consisted of four nitrogen doses in top dressing $(60,90,120$ and 150 $\mathrm{kg} \mathrm{ha}^{-1}$ ) and the second consisted of two forms of split applications [three equal applications $(1 / 3+1 / 3+1 / 3)$ of de dose; and one with increasing proportions $(1 / 6+2 / 6+3 / 6)$ of the dose in the first, second and third application, respectively]. Ammonium sulfate containing $21 \% \mathrm{~N}$ was used as nitrogen source.

Applications of $\mathrm{N}$ and $\mathrm{K}(45 \mathrm{~kg}$ $\mathrm{ha}^{-1}$ of $\mathrm{K}_{2} \mathrm{O}$, splitting the application $1 / 3+1 / 3+1 / 3$ ) were performed on the same date $[15,30$ and 50 days after emergence (DAE)] (Trani \& Raij, 1997). We used potassium chloride $\left(60 \% \mathrm{~K}_{2} \mathrm{O}\right)$.

The experimental design was of randomized blocks, with four replications. The experimental plot measured 2x1 m. The hybrid Belgrado $\left(\right.$ Bejo $^{\circledR}$ ) was sown manually on July 31,2013 , in four rows spaced $25 \mathrm{~cm}$. 21 days after sowing (DAS), plants were thinned, leaving a population of 20 plants per meter, spaced $5 \mathrm{~cm}$ apart. The two central lines of each plot were considered the useful area.

Weeds were controlled manually when necessary using weeding hoes between rows and plants. In the absence of rain, plants were irrigated using a sprinkler system. Diseases were controlled (leaf blight), using Amistar ${ }^{\circledR}$ (400 mL of i.a. ha ${ }^{-1}$ ) from the strobilurin chemical group.

Plants were harvested on November 8, 2013, 100 DAS, evaluating shoot height, fresh and dry matter weight of shoot and root, diameter, length and yield of twenty commercial roots. Dry matter was obtained after drying in an air-circulation oven heated at $65^{\circ} \mathrm{C}$ until constant weight using a precision balance $(0.1 \mathrm{~g})$. The evaluated physicochemical characteristics were (sample of three roots per plot): soluble solids, titratable acidity, maturation index (soluble solid/titratable acidity), $\mathrm{pH}$, carotenoid content and reducing sugars.

Soluble solids (SS) were determined according to recommendation made by AOAC (2005) and results expressed as ${ }^{\circ}$ Brix. Titratable acidity (TA) and $\mathrm{pH}$ were determined according to rules of Adolf Lutz Institute (Brasil, 2005). Acidity values were expressed as percentage of malic acid ( $\mathrm{g}$ of malic acid $100 \mathrm{~g}^{-1}$ fresh tissue). Maturation index was obtained through the relationship between SS and TA. Carotenoids were determined according to methodology described by AOAC (2005), and results expressed in $\mu \mathrm{g}$ g pulp ${ }^{-1}$, and reducing sugars (RS) determined by the methods described by Somogyi, adapted by Nelson (1944), and results expressed in percentage.

Data were submitted to analysis of variance and Tukey test (5\%) to compare the splittings and regression analysis to determine the effect of nitrogen doses on the evaluated characteristics. Control was considered as dose zero in the regression analysis. Analyses were performed with the Sisvar 5.3 program.

\section{RESULTS AND DISCUSSION}

There was no significant interaction between splitting and doses of nitrogen in top dressing on vegetative, production and physicochemical characteristics of carrot. Thus, the effects of the factors were discussed separately.

Effect of nitrogen doses - Shoot height in the splitting $1 / 3+1 / 3+1 / 3$ was not affected by nitrogen doses in top dressing, with an average of $42.16 \mathrm{~cm}$ (Figure 1). In the splitting 1/6+2/6+3/6 occurred a linear increase (Figure 1), however, despite being significant, differences were small, ranging from $40.92 \mathrm{~cm}$ with the dose zero to 43.95 $\mathrm{cm}$ with the highest dose (150 $\left.\mathrm{kg} \mathrm{N} \mathrm{ha}^{-1}\right)$. Shoot height observed in this study was similar to that found by Zanella \& Moreira (2013), $41.5 \mathrm{~cm}$, when the dose of $160 \mathrm{~kg}$ of $\mathrm{N} \mathrm{ha}^{-1}$ was applied and greater than that reported by Hailu et al. (2008), $20.44 \mathrm{~cm}$ when applying 411 $\mathrm{kg} \mathrm{N} \mathrm{ha}{ }^{-1}$. Moniruzzaman et al. (2013) found a little higher height, $47.36 \mathrm{~cm}$, when $130 \mathrm{~kg} \mathrm{~N} \mathrm{ha}^{-1}$ were supplied in top dressing dose. However, each author studied a different cultivar in different climatic and soil conditions, which can explain the differences.

Shoot fresh matter weight had a quadratic effect for $\mathrm{N}$ doses in the splitting $1 / 3+1 / 3+1 / 3$, with maximum estimated of $37.70 \mathrm{~g}$ applying $95 \mathrm{~kg}$ $\mathrm{N} \mathrm{ha}^{-1}$ in top dressing (Figure 1). In splitting $1 / 6+2 / 6+3 / 6$ a linear increase was observed (Figure 1), indicating that even higher doses of $\mathrm{N}$ used in top dressing were not enough for maximum production of fresh matter of shoots. So, 


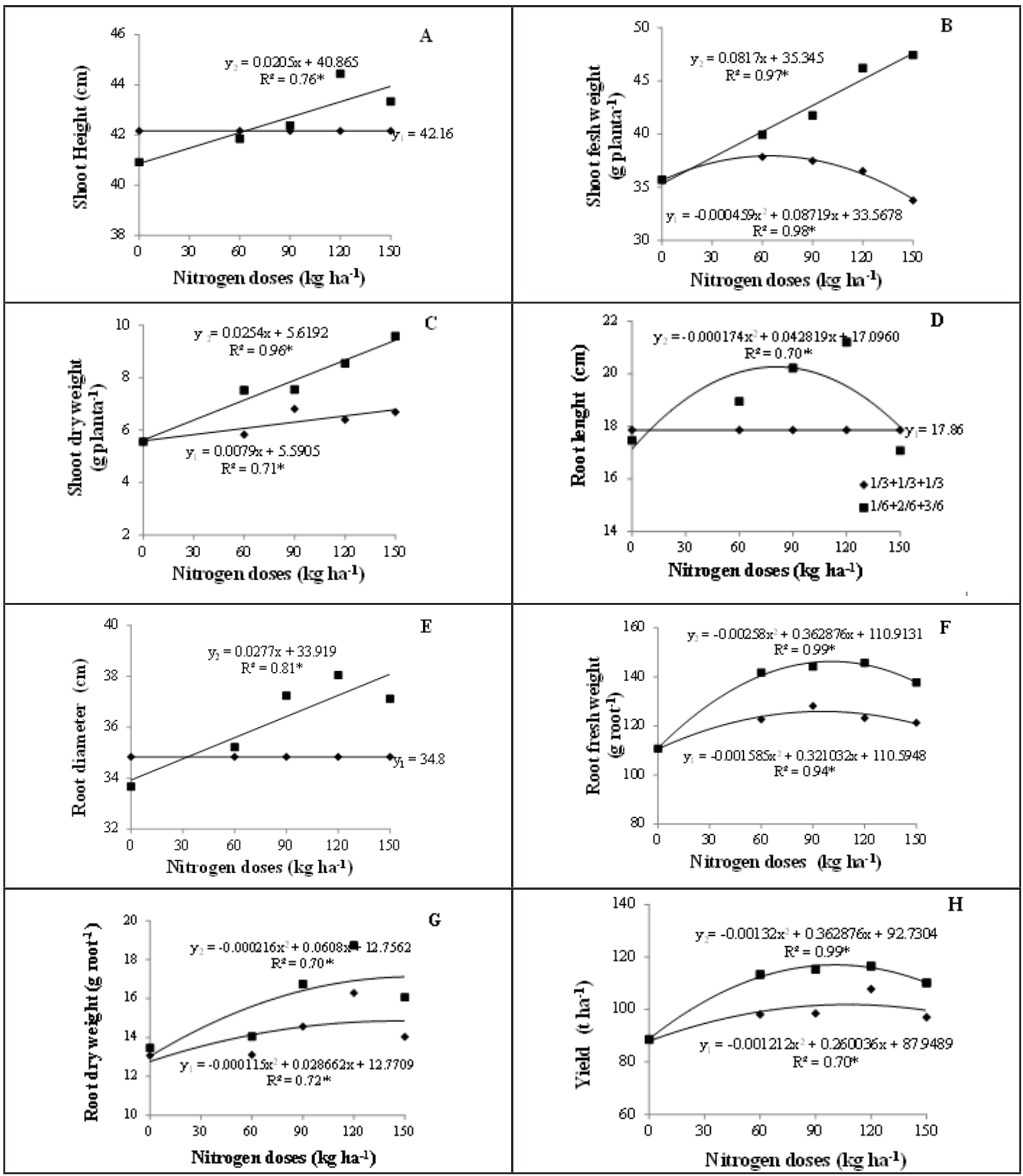

Figure 1. Shoot height (A), fresh (B) and dry weight of shoots $(C)$, length (D), diameter (E), fresh (F) and dry weight (G) of the root and yield $(\mathrm{H})$ of carrot plants depending on the $\mathrm{N}$ dose top dressing, splitting $1 / 3+1 / 3+1 / 3\left(\mathrm{y}_{1}\right)$ and $1 / 6+2 / 6+3 / 6\left(\mathrm{y}_{2}\right)$. Botucatu, UNESP, 2013 .

besides little differences in shoot height, fresh weight was influenced by $\mathrm{N}$ doses.

Shoot dry weight increased linearly in both splittings, with an estimated maximum value of 6.77 and $9.42 \mathrm{~g}$ plant $^{-1}$, in splittings $1 / 3+1 / 3+1 / 3$ and
$1 / 6+2 / 6+3 / 6$, respectively, for the highest dose $\left(150 \mathrm{~kg} \mathrm{ha}^{-1}\right)$ (Figure 1). Usually, $\mathrm{N}$ favors plant development and growth, resulting in increasing dry matter accumulation, except when used in excess (Luz et al., 2009). Cecílio
Filho \& Peixoto (2013) obtained for 'Forto' carrot $5.45 \mathrm{~g}$ of shoot dry matter accumulation. According to the authors, the differences in cumulative amounts of dry matter in the shoot may be due to cultivars and/or climatic conditions, 


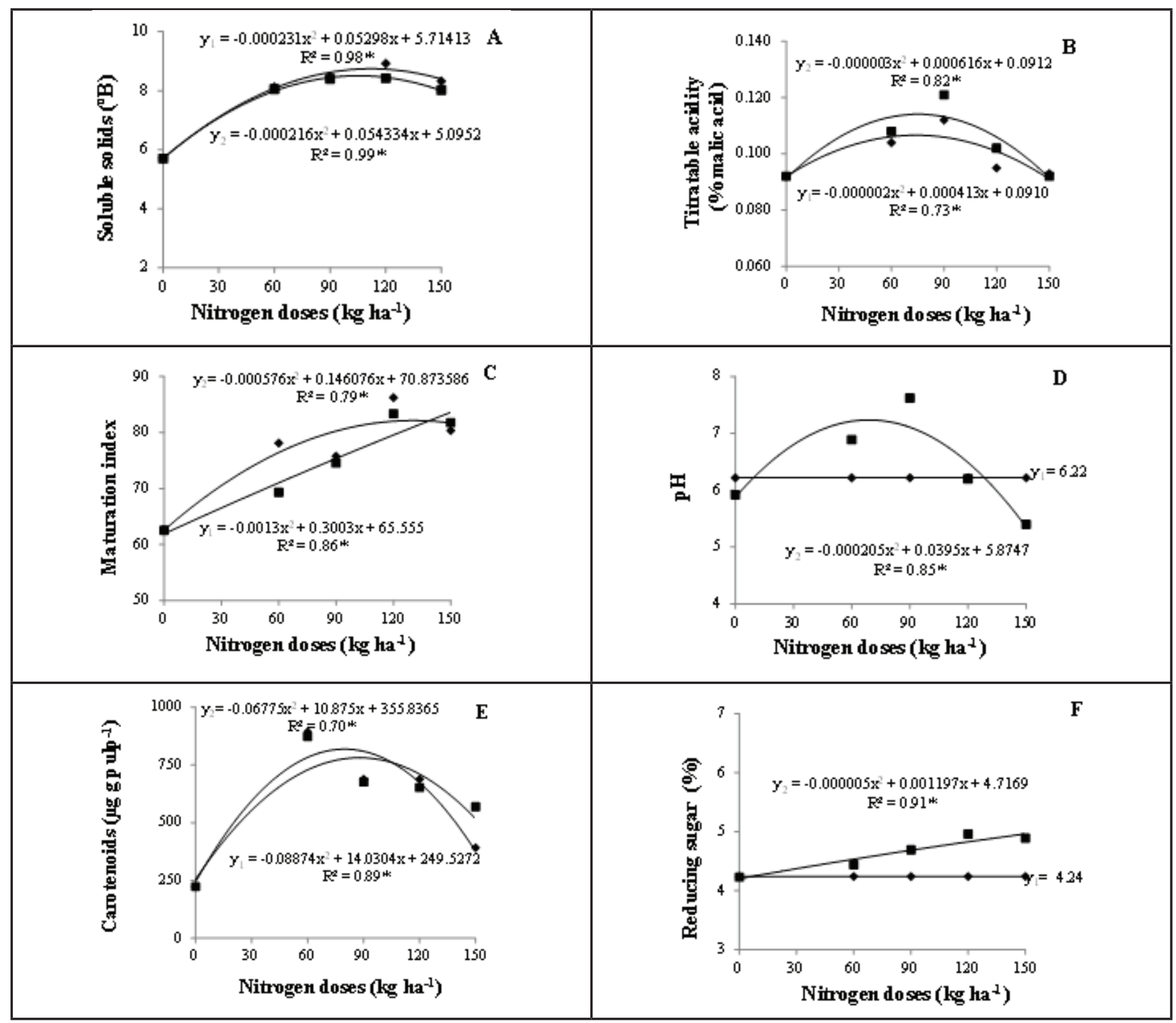

Figure 2. Content of soluble solids (A), titratable acidity (B), maturation index (C), pH (D), carotenoids (E) and reducing sugar contents (F) in the root of the carrot, in function of $\mathrm{N}$ doses in top dressing, splitting 1/3+1/3+1/3 $\left(\mathrm{y}_{1}\right)$ and 1/6+26+3/6 ( $\left.\mathrm{y}_{2}\right)$. Botucatu, UNESP, 2013 .

soil fertility and plant nutrition.

Length and diameter of the root in the splitting $1 / 3+1 / 3+1 / 3$ were not affected by $\mathrm{N}$ doses in top dressing, with averages of $17.86 \mathrm{~cm}$ and 34.83 $\mathrm{mm}$, respectively (Figure 1). In splitting $1 / 6+2 / 6+3 / 6$ the effect of nitrogen doses in top dressing on the length was quadratic, with maximum estimated value of $19.73 \mathrm{~cm}$ for the dose of $123 \mathrm{~kg}$ $\mathrm{Nha}^{-1}$ (Figure 1). The diameter presented linear response, with maximum value of $38.17 \mathrm{~mm}$ at the highest dose $(150 \mathrm{~kg}$ ha $^{-1}$ ). Mubashir et al. (2010) reported an increase in root length and diameter quadratically with increasing nitrogen fertilizer, reaching greater length (13 $\mathrm{cm})$ with $150 \mathrm{~kg} \mathrm{~N} \mathrm{ha}^{-1}$ and larger diameter $(34 \mathrm{~mm})$ at the dose of 200 $\mathrm{kg} \mathrm{N} \mathrm{ha}{ }^{-1}$. Increase in root length was also observed by Moniruzzaman et al. (2013), with the longest length (17.19 $\mathrm{cm})$ obtained with the dose of $100 \mathrm{~kg} \mathrm{~N}$ $\mathrm{ha}^{-1}$. Zanella \& Moreira (2013) showed a greater length $(13.94 \mathrm{~cm})$ and diameter $(11.77 \mathrm{~mm})$ with application of 160 $\mathrm{kg} \mathrm{N} \mathrm{ha}{ }^{-1}$. For Hailu et al. (2008), the highest length $(14.74 \mathrm{~cm})$ and diameter $(33.6 \mathrm{~mm})$ were obtained using $274 \mathrm{~kg}$ $\mathrm{N} \mathrm{ha}^{-1}$ in combination with $309 \mathrm{~kg} \mathrm{ha}^{-1}$ of $\mathrm{P}$ from organic origin. The size of the root is a feature of determining the yield and root quality, since carrots are sorted by the trade centers, as CEAGESP, according to its size. On average, the roots produced in this study were within the marketing standards and were classified in class 18 , where the length varies from 18 to $22 \mathrm{~cm}$ (CEAGESP, 2014).

For fresh and dry root weight, quadratic effects for $\mathrm{N}$ doses were observed in both splittings (Figure 1). The maximum estimated fresh root weights were 126.85 and $148.71 \mathrm{~g}$ in the $\mathrm{N}$ doses of 101 and $136 \mathrm{~kg} \mathrm{ha}^{-1}$, in splittings $1 / 3+1 / 3+1 / 3$ and $1 / 6+2 / 6+3 / 6$, respectively (Figure 1). The values were considered high when compared to those obtained by Moniruzzaman et al. (2013), which was $68.33 \mathrm{~g}$ with a dose 
Table 1. Comparison of means of the characteristics shoot height (SH), fresh (FWS) and dry (DWS) weight of the shoot, fresh (FWR) and dry (DWR) weight of the root, root length (RL), root diameter (RD), yield, soluble solids (SS), titratable acidity (TA), maturation index (MI), hydrogen potential (pH), reducing sugars (RS) and carotenoid content (CC) for the two splittings. Botucatu, UNESP, 2013.

\begin{tabular}{|c|c|c|c|c|c|c|c|c|}
\hline \multirow{2}{*}{ Splitting } & \multirow{2}{*}{$\mathrm{SH}(\mathrm{cm})$} & FWS & DWS & FWR & DWR & \multirow{2}{*}{ RL (cm) } & \multirow{2}{*}{ RD (mm) } & \multirow{2}{*}{ Yield $\left(t h^{-1}\right)$} \\
\hline & & \multicolumn{4}{|c|}{ (g) } & & & \\
\hline $1 / 3+1 / 3+1 / 3$ & $42.67 \mathrm{a}$ & $36.89 b$ & $6.25 \mathrm{a}$ & $125.45 b$ & $13.51 \mathrm{a}$ & $17.73 \mathrm{a}$ & $34.43 b$ & $100.36 \mathrm{~b}$ \\
\hline $1 / 6+2 / 6+3 / 6$ & $43.39 \mathrm{a}$ & $42.03 \mathrm{a}$ & $7.75 \mathrm{a}$ & $142.32 \mathrm{a}$ & $14.34 \mathrm{a}$ & $18.01 \mathrm{a}$ & $36.02 \mathrm{a}$ & $113.85 \mathrm{a}$ \\
\hline \multirow[t]{2}{*}{ CV (\%) } & 8.32 & 15.71 & 11.55 & 11.55 & 14.34 & 7.48 & 5.46 & 11.99 \\
\hline & SS ( ${ }^{\circ}$ Brix) & \multicolumn{2}{|c|}{ TA (\% malic acid) } & (MI) & $\mathrm{pH}$ & RS (\%) & \multicolumn{2}{|c|}{ CC $\left(\mu\right.$ g g pulp $\left.^{-1}\right)$} \\
\hline $1 / 3+1 / 3+1 / 3$ & $8.45 \mathrm{a}$ & \multicolumn{2}{|c|}{$0.101 \mathrm{a}$} & $82.61 \mathrm{a}$ & $6.53 a$ & $4.24 \mathrm{a}$ & \multicolumn{2}{|c|}{$651.03 \mathrm{~b}$} \\
\hline $1 / 6+2 / 6+3 / 6$ & $8.22 \mathrm{a}$ & \multicolumn{2}{|c|}{$0.106 \mathrm{a}$} & $77.21 \mathrm{~b}$ & $5.30 \mathrm{a}$ & $4.74 \mathrm{a}$ & \multicolumn{2}{|c|}{$697.91 \mathrm{a}$} \\
\hline CV (\%) & 5.82 & \multicolumn{2}{|c|}{14.77} & 11.17 & 1.39 & 11.23 & \multicolumn{2}{|c|}{11.99} \\
\hline
\end{tabular}

Means followed by same letters in the columns do not differ by Tukey's test, $5 \%$.

of $100 \mathrm{~kg} \mathrm{ha}^{-1}$ and Zanella \& Moreira (2013), where the fresh root weight had not reached $100 \mathrm{~g}$, even using the highest $\mathrm{N}$ dose $\left(160 \mathrm{~kg} \mathrm{ha}^{-1}\right)$. Other studies also show weights lower than $100 \mathrm{~g} \mathrm{plant}^{-1}$ (Hailu et al., 2008).

Maximum averages estimated for dry matter of the root were 14.55 and 17.03 $\mathrm{g}$, obtained with doses of 125 and 140 $\mathrm{kg} \mathrm{N} \mathrm{ha}^{-1}$, in splittings $1 / 3+1 / 3+1 / 3$ and $1 / 6+2 / 6+3 / 6$, respectively (Figure 1). Similar results were obtained by Cecílio Filho \& Peixoto (2013), who obtained $17.81 \mathrm{~g}$ of dry matter accumulation evaluating 'Forto' carrot.

For yield, a quadratic effect was obtained for $\mathrm{N}$ doses in both splittings. Splitting $1 / 3+1 / 3+1 / 3$ the highest yield (107.70 $\mathrm{tha}^{-1}$ ) was estimated for the dose of $102 \mathrm{~kg} \mathrm{~N} \mathrm{ha}^{-1}$ and, in the splitting $1 / 6+2 / 6+3 / 6$, the highest yield $(117.66$ $\left.\mathrm{t} \mathrm{ha}^{-1}\right)$ was estimated with the dose of $138 \mathrm{~kg} \mathrm{~N} \mathrm{ha}^{-1}$ (Figure 1). Regarding the recommended (60 to $120 \mathrm{~kg} \mathrm{~N} \mathrm{ha}^{-1}$ in top dressing) for the State of São Paulo (Trani \& Raij, 1997), we observed that the estimated dose for maximum yield in the splitting $1 / 6+2 / 6+3 / 6$ was slightly higher than the maximum recommended (120 $\left.\mathrm{kg} \mathrm{N} \mathrm{ha}^{-1}\right)$. However, this recommendation bulletin was issued a long time ago and probably the current hybrids demand a greater amount of nutrients to be able to express all their productive potential.

The average yield obtained in this research may be considered high for the crop, when compared to other researches. Moniruzzaman et al. (2013) related a maximum yield of $20.67 \mathrm{tha}^{-1}$ using $100 \mathrm{~kg} \mathrm{~N} \mathrm{ha}^{-1}$ in top dressing, while Hailu et al. (2008) obtained the maximum yield of $20 \mathrm{t} \mathrm{ha}^{-1}$ using 274 $\mathrm{kg} \mathrm{N} \mathrm{ha-1}$. Luz et al. (2009) reported a maximum yield of $37.0 \mathrm{t} \mathrm{ha}^{-1}$ topdressing with nitrogen, potassium and calcium.

The high yields obtained in this study were probably due to the climate which was favorable to plants development during the experiment, with an average temperature of $18^{\circ} \mathrm{C}$, which is close to the ideal temperature range for a good development of carrots $\left(10\right.$ to $\left.15^{\circ} \mathrm{C}\right)$. There was also less rainfall in early development, which provided uniform standards with few failures and the almost absence of pest and disease, the incidence of leaf blight only occurring near the end of the cycle and easily controlled. Furthermore, hybrids, in most cases, present greater uniformity and heterosis, favoring the attainment of higher yields (Maluf, 2001), as obtained, also, by Zanfirov et al. (2012), 96 to $104 \mathrm{t} \mathrm{ha}^{-1}$, studying potassium doses. Most authors cited studied open pollinated cultivars that can be less productive. The high productivity can also be linked to the nitrogen source used (ammonium sulfate). According to Alves et al. (2009), the greater efficiency associated to ammonium sulfate is the presence of sulfur $(23 \%)$ contained in the composition of this fertilizer. As described Mendonça \& Peixoto (1991), sulfur is an important nutrient for the production of proteins and chlorophyll, and is a component of some plant hormones which enhances root growth, and increase yield.

Some authors claim that for tuberous roots production do not exist correlation between fresh weight of aerial part, which is greatly affected by nitrogen fertilization, and the productivity of roots. However, this statement is only true within certain limits, because shoot growth is not always synonymous of increasing productivity (Guimarães et al., 2002). In this study, for the splitting $1 / 6+2 / 6+3 / 6$, this correlation between height and fresh weight of the shoot and yield was not maintained with the highest dose $\left(150 \mathrm{~kg} \mathrm{~N} \mathrm{ha}^{-1}\right)$. While the vegetative characteristics (shoot height and fresh weight) presented a linear effect, that is, with increases up to the highest dose, the yield showed a quadratic effect, increasing until 138 $\mathrm{kg} \mathrm{N} \mathrm{ha-1}$ with a subsequent reduction in higher doses, showing that excess of $\mathrm{N}$ may favor only the vegetative growth.

For SS contents and titratable acidity (TA) quadratic effects were obtained and, in the splitting $1 / 3+1 / 3+1 / 3$, the maximum levels of SS and TA in the carrot root were estimated on $8.75^{\circ} \mathrm{Brix}$ and $0.112 \%$, obtained with 114 and 103 $\mathrm{kg} \mathrm{ha}^{-1}$ of $\mathrm{N}$ doses, respectively (Figure 2). Splitting $N$ doses on $1 / 6+2 / 6+3 / 6$, the estimated maximum levels were $8.51^{\circ}$ Brix and $0.122 \%$ with $\mathrm{N}$ doses of 114 and $103 \mathrm{~kg} \mathrm{ha}^{-1}$. The SS contents are close to those obtained by other authors who reported values ranging from 7.1 to $10.9^{\circ}$ Brix (Alves et al., 2010; Soares et al., 2010; Ferreira et al., 2011; Figueiredo Neto et al., 2011). The TA values were lower than those reported by other authors, ranging from 0.17 to 0.69\% (Alves et al., 2010; Soares et al., 2010; Figueiredo Neto et al., 2011). These differences are probably due to 
cultivars, most of the time 'Brasilia', and the differences in climate and farming.

A quadratic effect for maturation index (SS/TA) was also observed, being the maximum estimated value 82.89 in the splitting $1 / 3+1 / 3+1 / 3$ applying $115 \mathrm{~kg} \mathrm{~N} \mathrm{ha}^{-1}$ and for the splitting $1 / 6+2 / 6+3 / 6$, the maximum value was estimated in 80.13 , applying $126 \mathrm{~kg}$ $\mathrm{N} \mathrm{ha}^{-1}$ (Figure 2). Alves et al. (2010) obtained lower values (50.15 to 59.85) for this relationship evaluating cultivars Brasília, Alvorada and Esplanada. Figueiredo Neto et al. (2011) also reported lower values (30.8) evaluating 'Brasília' carrot.

Nitrogen doses in top dressing did not affect the reducing sugars (RS) content in the splitting $1 / 3+1 / 3+1 / 3$, averaging $4.24 \%$. In the splitting $1 / 6+2 / 6+3 / 6$, quadratic effect was observed, with a maximum estimated value of $4.78 \%$ applying $119.7 \mathrm{~kg} \mathrm{~N} \mathrm{ha}^{-1}$ (Figure 2). Maringoni et al. (2012) found lower values of RS (1.48\%) testing 'Nantes' carrot.

The $\mathrm{pH}$ of roots in the splitting $1 / 3+1 / 3+1 / 3$ was not influenced by nitrogen doses, averaging 6.22. With the splitting $1 / 6+2 / 6+3 / 6$ the estimated maximum value of the root $\mathrm{pH}$ was 7.77 with the dose of $96 \mathrm{~kg} \mathrm{~N} \mathrm{ha}^{-1}$ (Figure 2). The observed values do not differ much from those obtained by other authors, who reported values ranging from 5.5 to 6.2 (Alves et al., 2010; Soares et al., 2010; Ferreira et al., 2011).

A quadratic effect was observed for carotenoids content. The maximum estimated values were 804.09 and 792.24 $\mu \mathrm{g} \mathrm{g}$ pulp $^{-1}$, in splittings $1 / 3+1 / 3+1 / 3$ and $1 / 6+2 / 6+3 / 6$ respectively, applying doses of 79 and $80 \mathrm{~kg} \mathrm{~N} \mathrm{ha}^{-1}$ (Figure 2). So, lack or excess of $\mathrm{N}$ can be harmfull for this characteristic, very important for root quality. Figueiredo Neto et al. (2011) obtained values of $896 \mu \mathrm{g} \mathrm{g} \mathrm{pulp}^{-1}$ for the 'Brasília' carrot.

So it is clear that lack or excess of $\mathrm{N}$ in top dressing can affect root quality on its physicochemical characteristics. Nowadays, these characteristics are not valued, but it can be in the future, mainly in markets that value healthy eating.

Effect of $\mathbf{N}$ application splitting Comparing splittings, the averages of fresh weight of shoot and root, root diameter and yield were higher in splitting $1 / 6+2 / 6+3 / 6$ than in $1 / 3+1 / 3+1 / 3$ (Table 1 ). These results indicate that the application of $\mathrm{N}$ in increasing proportions $(1 / 6+2 / 6+3 / 6)$ possibly permit its more effective use by the plant, favoring vegetative growth of shoots and, consequently, causing greater translocation of photoassimilates to the roots, providing greater root diameter and fresh weight and yield.

Nitrogen applyed in the splitting $1 / 6+2 / 6+3 / 6$ corresponds to the highest amount after 57 DAS, probably indicating that greater amount of this nutrient was provided at the time of greater demand for the carrot plants, as the carrot root develops primarily in length that goes up to about 60 DAS. After this period an increase in diameter occurr (60-100 DAS), and reserves are accumulated. So, it is useless to provide high amount of easily leachable nutrients early in the cycle, due to the efficiency of its use possibly be low, resulting in leaching or volatilization of the excess. In accordance with Cecílio Filho \& Peixoto (2013), the absorption of macronutrients by the 'Forto' carrot occurs in small amounts up to 50 days after sowing, both on the root and shoot. Thereafter, extraction rates are intense from 80 to 90 DAS, depending on the nutrient, Vieira Filho et al. (2014), testing five splittings ( 0,1 , 2, 3, 4 and 5) through irrigation water for the 'Brasilia' carrot, observed that, the greater the number of splittings, the greater the fresh weight, length and diameter of the root. Zanella \& Moreira (2013) achieved higher yield with a dose of $160 \mathrm{~kg} \mathrm{~N} \mathrm{ha}^{-1}$ in top dressing applied at 15, 30 and 50 DAE. Hailu et al. (2008) concluded that the application of $274 \mathrm{~kg} \mathrm{~N} \mathrm{ha}^{-1}$ in top dressing with three applications (in the emergency, two months after planting and a month before harvest), increased the yield. Luz et al. (2009), evaluating different top dressing treatments with nitrogen, potassium and calcium, found that the joint application of these nutrients at 30 and 45 DAS increased the yield of commercial roots. Greater values of carotenoid content, were obtained in splitting $1 / 6+2 / 6+3 / 6$. Despite the carotenoid content not being a prized feature commercially (unless it affects the color of the root), it is important from nutritional point of view, because carotenoids are precursors of vitamin A and carrots are a major source for human beings. Therefore, splitting $1 / 6+2 / 6+3 / 6$, in addition to promoting increased yield, also favors nutritional quality, increasing the carotenoid content.

Most of the studied characteristics showed a quadratic effect for nitrogen doses in top dressing, with an estimated maximum yield of $117.7 \mathrm{t} \mathrm{ha}^{-1}$ for the dose of $138 \mathrm{~kg} \mathrm{~N} \mathrm{ha}^{-1}$. Higher values for fresh weight of shoot and root, root diameter, yield and carotenoid content were obtained with the splitting $1 / 6+2 / 6+3 / 6$.

\section{REFERENCES}

ALVES, SSV; NEGREIROS, MZ; AROUCHA, EMM; LOPES, WAR; TEÓFILO, TMS; FREITAS, FCL; NUNES, GHS. 2010. Quality of carrot roots under different population densities. Revista Ceres 57: 218-223.

ALVES, AU; OLIVEIRA, AP; ALVES, EU; OLIVEIRA, ANP; CARDOSO, EA; MATOS, BF. 2009. Management of nitrogen fertilization for sweet potato: sources and application parceling. Ciência Agrotecnologica 33: 1554-1559.

ASSOCIATION OF OFFICIAL ANALYTICAL CHEMISTRY. 2005. Official methods of analysis of the association of official analytical chemistry. 11 ed. Maryland, p.1141.

BRASIL. 2005. Métodos fisico-químicos para análise de alimentos. Brasil: Ministério da Saúde. p.1018.

BREDEMEIER, C; MUNDSTOCK, CM. 2000. Regulation of nitrogen absortion and assimilation in plants. Ciência Rural 30: 365-372.

CEAGESP (Companhia de Entreposto e Armazéns Gerais de São Paulo). Normas de classificação de Cenoura. 2014. Available at $<\mathrm{http}: / /$ www.ceagesp.gov.br/produtor/classific/ fc cenoura $>$. Accessed on February 15.

CECÍLIO FILHO, AB; PEIXOTO, FC. 2013. Acumulation and exportation of nutrients by carrot 'Forto'. Revista Caatinga 26: 64-70.

FERREIRA, RMA; AROUCHA, EMM; MESQUITA, HC; FREITAS, FCL; NUNES, GHS. 2011. Quality carrot powder-crop during development in monoculture and associated radish. Revista Ciência Agronômica 42: 423-428.

FIGUEIREDO NETO, A; OLIVEIRA, SB; LIMA, MS; AMORIM, MR; FIGUEIREDO, RMC. 2011. Influence of organic composition in the physicochemical characteristics of the "Brasília" carrot in the city of Petrolina (PE). Revista Semiárido De Visu 1: 3-9. 
GUIMARÃES, VF; ECHER, MM; MINAMI, K. 2002. Métodos de produção de mudas, distribuição de matéria seca e produtividade de plantas de beterraba. Horticultura Brasileira 20: 505-509.

HAILU, S; SEYOUM, T; DECHASSA, N. 2008. Effect of combined application of organic-P and inorganic- $\mathrm{N}$ fertilizers on yield of carrot. Africa Journal Biotechnol 7: 27-34.

LUZ, JMQ; ZORZAL FILHO, A; RODRIGUES, WL; RODRIGUES, CR; QUEIROZ, AA. 2009. Top-dressing fertilization with nitrogen, potassium and calcium in the root yield of carrots. Horticultura Brasileira 27: 543-548.

MALUF, WR. 2001. Heterose e emprego de híbridos $F_{1}$ em hortaliças. In: NASS, LL; VALOIS, ACC; MELO, IS; VALADARES, MC. (eds). Recursos genéticos e melhoramento. Fundação MT. p.327-356.

MARINGONI, AC; BALDINI, LFG; DEMANT, LAR; EVANGELISTA, RM; FUJITA, E.
2012. Fungicide action in the control of leaf blight and the carrot cv. Nantes physicalchemical characteristics. Revista Brasileira Produtos Agroindustriais 14: 161-165.

MENDONÇA, ATC; PEIXOTO, N. 1991. Effects of spacing and fertilizer levels in sweet potato cultivars. Horticultura Brasileira 9: 80-82.

MONIRUZZAMAN, M; AKAND, MH; HOSSAIN, MI; SARKAR, MD; ULLAH, A. 2013. Effect of nitrogen on the growth and yield of carrot (Daucus carota L.). The Agriculturists 11: 76-81.

MUBASHIR, M; MALIK, AS; KHAN, AA; ANSARI, TM; WRIGHT, S; BROWN, MV; ISLAM, KR. 2010. Growth, yield and nitrate accumulation of irrigated carrot and okra in response to nitrogen fertilization. Pakistan Journal Botany 42: 2513-2521.

NELSON, NA. 1944. A photometric adaptation of Somogy method for the determination of glucose. Journal Biological Chemistry 31:
159-161.

SILVA, MG; ARF, O; SÁ, ME; RODRIGUES, RAF; BUZETTI, S. 2004. Nitrogen fertilization and soil management of winter common bean crop. Scientia Agrícola 61: 307-312.

SOARES, IAA; FREITAS, FCL; NEGREIROS, MZ; FREIRE, GM; AROUCHA, EMM; GRANGEIRO, LC; LOPES, WAR; DOMBROSKI, JLD. 2010. Weed interference in carrot yield and quality. Planta Daninha 28: $247-254$

TRANI, PE; RAIJ, BV. Hortaliças. In: RAIJ, BV. 1997. Recomendações de adubação e calagem para o Estado de São Paulo. Campinas: Instituto Agronômico \& Fundação IAC. p.285.

VIEIRA FILHO, PS; OLIVEIR, GO; BISCARO, GA; SILVA, LB; SOUZA, MAS. 2014. Parcelamento de nitrogênio via água de irrigação na cultura de cenoura. In: II INOVAGRI Interna 